一材料となるものである。

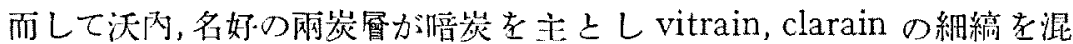
ずる詹竾である事賽は，石炭㟔石學上，その生成は狄䉝り原地堆皘に非ずし て多少水流の影響の隹せし環境に生成せる事老示すものである (未完)。

\title{
二上山産柘榴石の碑究 (II)
}

Studies of garnets in the andesites forming the volcano Nijô-san (II)

理學土大 森 繁一(K. Ohmori)

\section{VI 柾 榴 石}

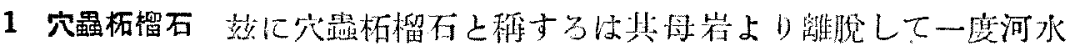
により運搬沈㫢せるものである。この柘榴石に就いては神渄先生の詳細な 研究がある。炎にこの琶整在述べよう。

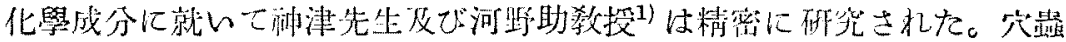

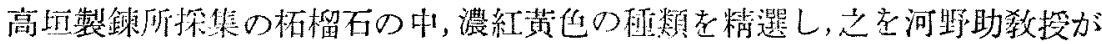
分析された。その化學式は $\left(\mathrm{Fe}^{\prime \prime}{ }_{8} \mathrm{Fe}^{\prime \prime}{ }_{199} \mathrm{Mg}_{38} \mathrm{Mn}_{12} \mathrm{Ca}_{43}\right)_{300} \mathrm{Al}_{200}\left[\mathrm{SiO}_{4}\right]_{300}$ 上

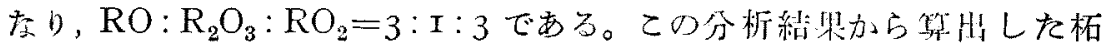
榴不端成分分子比は $\mathrm{Alm}=67.66 \%, \mathrm{Py}=\mathrm{I} 3.20 \%, \mathrm{Sp}=4 . \mathrm{I} 3 \%, \mathrm{Gr}=$ $8.58 \%$ 及び And $=6.43 \%$ である2。

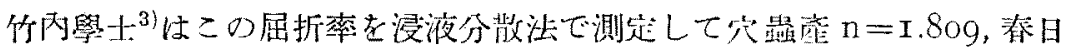
南 $\mathrm{n}=\mathrm{r}$.8工o なる結果を得られた。

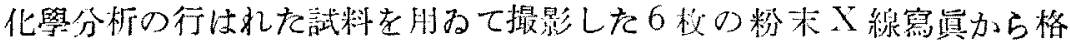

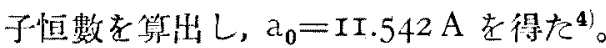

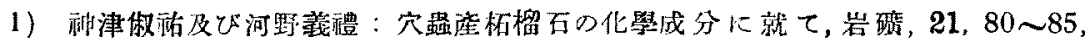
昭 14 .

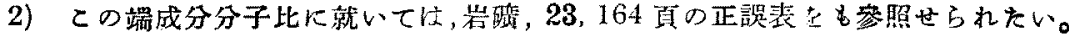

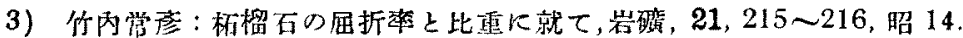

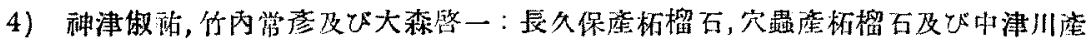

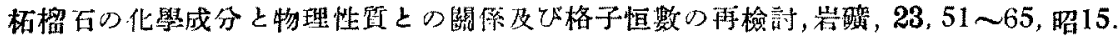




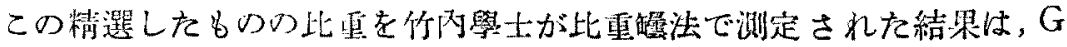
$\left(\right.$ at $\left.4^{\circ} \mathrm{C}\right)=4.104$ である1)。

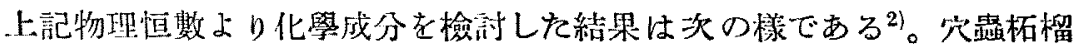

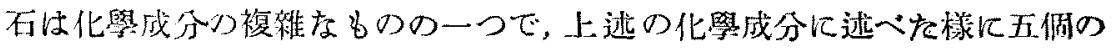
端成分を總て含有し，ての中最も少量のものでも $\mathrm{Sp}=4.13 \mathrm{~mol} \%$ であ る。神津先生の提栄された方法で，物理恒數から化學成分を算出する沉は 聯立五元一次才程式を必要とし，これには $\mathrm{n}, \mathrm{G}$ 及び $\mathrm{a}_{\mathbf{0}}$ の他に一恒數を必

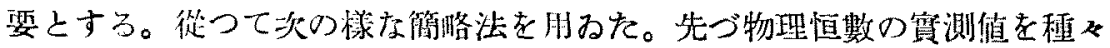
の計算で吟味し，修正物理洹數老求める。次に $\mathrm{Alm}+\mathrm{Py}, \mathrm{Gr}+\mathrm{And}$ 或 は $A l m+S p$ の周溶體考考入,其各々が一成分を成すとして聯立四元一次 方程式で界出する。かくして得た各成分百分比の平均値は $\mathrm{AIm}=67.34 \%$, $\mathrm{Py}=\mathrm{I} 3.07 \%, \mathrm{Sp}=4.5 \mathrm{I} \%, \mathrm{Gr}=8.64 \%$ 及び And $=6.44 \%$ と度り，之 は上記化學分析よりの百分比と良く一致する。

2 黑雲母岀山岩中の柘㨨石 この柘㨨石の屈折率之格子恒數は次の椂で ある。

届折花等士の测定された属折率は次の樣である3)。

柘榴石 \begin{tabular}{cc}
$\begin{array}{c}\text { (Rock No. 9) } \\
\text { (Rock No. 10) }\end{array}$ & $\mathrm{n}=1.808 \mathrm{~A}$ \\
\hline 平 均 & $\mathrm{n}=1.808 \mathrm{~A}$
\end{tabular}

この結果は上記穴虽炻榴石 $\mathrm{n}=\mathrm{I} .809$ と筫驗誤䔄內で一玫する。

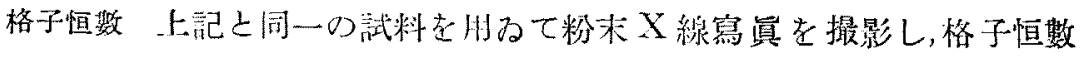

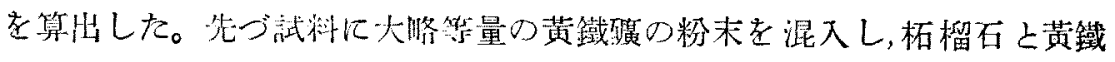

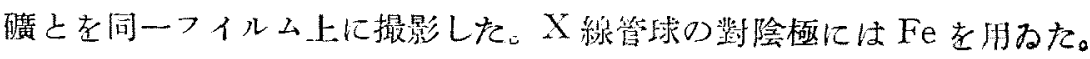

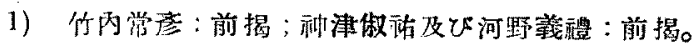

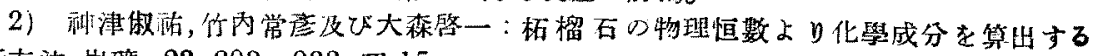
新方法，岩磼，23，203〜233，昭 15.

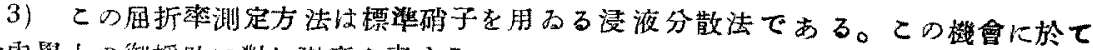

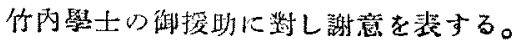


黃鐵礦の反射線間距離をコンパレーターで测定して補正曲線を作り，ての 曲線を肘るて柘榴石の反射線開测定距離を衫正し，格子恒数を算活した。 異るカメラを使用して得を結果は次の樣である。

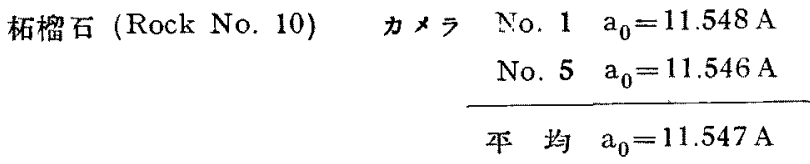

向この試料は捕獲岩を有する㫮鍳母安山岩中の柘榴石である。捕獲岩を 有しない安川岩の夫に就いて同絿に䔈驗し次の結果老得た。

顺媹石 (Rock No. A-1) カx \begin{tabular}{ll} 
No. 1 & $a_{0}=11.547 \mathrm{~A}$ \\
& No. $4 \mathrm{a}_{0}=11.546 \mathrm{~A}$ \\
No. 5 & $\mathrm{a}_{0}=11.544 \mathrm{~A}$ \\
\hline 平 均 $\mathrm{a}_{0}=11.546 \mathrm{~A}$
\end{tabular}

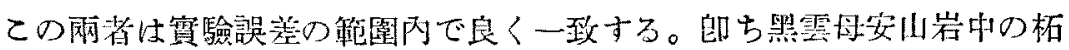

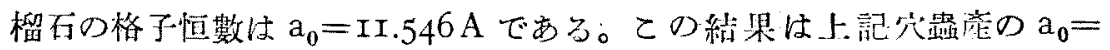

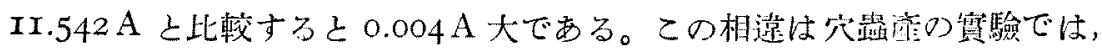

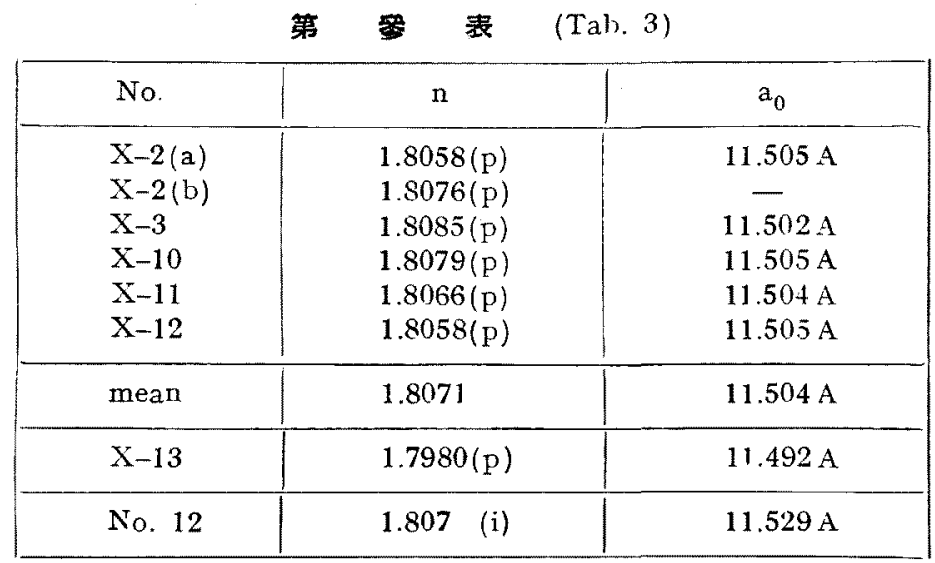

（P）プリズム法の測定 (i) 浸液分散法の湘定

黃鐵礦粉末を柘榴石粉末に混入甘ずして,各ょ別のフイルムに撮影し, 前者

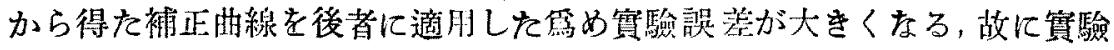


第四表

\begin{tabular}{|c|c|c|c|c|c|c|c|}
\hline \multirow{2}{*}{ No. } & 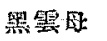 & \multicolumn{3}{|c|}{ 斜 長 } & \\
\hline & $\left(00^{\gamma}[)\right.$ & $\begin{array}{c}a^{\prime} \\
(001)\end{array}$ & $\begin{array}{c}\gamma^{\prime} \\
(001)\end{array}$ & $\%$ An & $\begin{array}{l}\text { 柘榴G } \\
\text { garnet }\end{array}$ & $\begin{array}{l}\text { 斜辰盾 } \\
\text { plagio. }\end{array}$ & $\begin{array}{l}\text { 黑需舟 } \\
\text { biotite }\end{array}$ \\
\hline$x-2$ & - & 1.567 & 1.571 & 72 & + & + & + \\
\hline$x-3$ & 1.643 & $\left\{\begin{array}{l}1.568 \\
1.552\end{array}\right.$ & $\left\{\begin{array}{l}1.571 \\
1.557\end{array}\right.$ & $\left\{\begin{array}{l}73 \\
46\end{array}\right.$ & + & + & $t$ \\
\hline$x-10$ & 1.648 & 1.557 & 1.561 & 53 & + & + & + \\
\hline $\mathrm{X}-11$ & 1.643 & 1.566 & 1.570 & 70 & + & + & + \\
\hline$X-12$ & 1.643 & $\left\{\begin{array}{l}1.566 \\
1.552\end{array}\right.$ & $\left\{\begin{array}{l}1.570 \\
1.557\end{array}\right.$ & $\left\{\begin{array}{l}70 \\
46\end{array}\right.$ & $t$ & + & + \\
\hline$X-13$ & 1. 648 & $\left\{\begin{array}{l}1.565 \\
1.553\end{array}\right.$ & $\left\{\begin{array}{l}1.569 \\
1.559\end{array}\right.$ & $\left\{\begin{array}{l}68 \\
47\end{array}\right.$ & + & + & + \\
\hline To. 12 & & & d. & & + & - & + \\
\hline
\end{tabular}

1) porphyroblastic

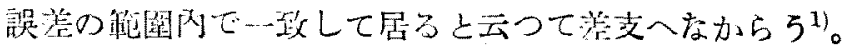

3 捕獲岩中の柘㨨石 同梯の力法で求めた捕擭岩中の柘榴石の屈折案之

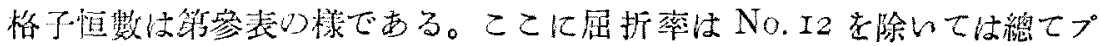
リズム法で测定した。

同表に見る栐に捕獲炭の $\mathrm{X}-2$ 加ら $\mathrm{X}-\mathrm{I} 2$ 迄り六種に於て屈折率は I.8058 I.8085で栵めて近似である。又格子恒数当II.502AからII.505A

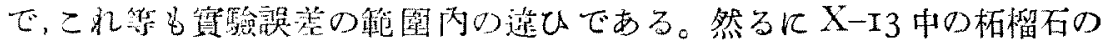

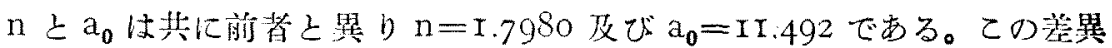

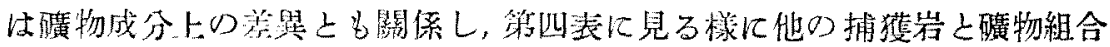
せを異にする。同母岩中には多量のグラスを存するのは高度の pyrometamorphism 在受けた證據之推される。

變成作用り程度の最名低いと考へられる品雲母粘板岩 (No. I2) 中の柘

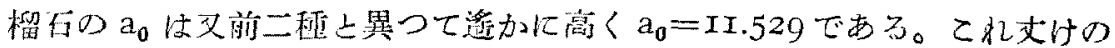

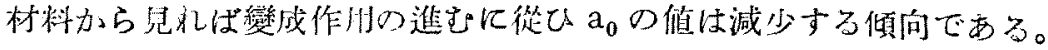

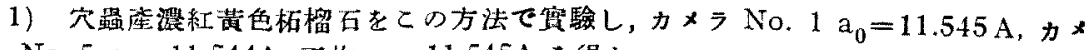
亏 No. $5 a_{0}=11.544 \mathrm{~A}$, 平均 $a_{0}=11.545 \mathrm{~A}$ 得た。 
('Tab. 4)

\begin{tabular}{|c|c|c|c|c|c|c|c|c|}
\hline \multicolumn{9}{|c|}{ 礦物組合 (mineral assemblage) } \\
\hline $\begin{array}{l}\text { 皘線石 } \\
\text { sillim. }\end{array}$ & 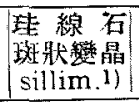 & $\begin{array}{l}\text { 慳青石 } \\
\text { cordie. }\end{array}$ & $\begin{array}{l}\text { 十字石 } \\
\text { staurol. }\end{array}$ & $\begin{array}{l}\text { 紅杜互 } \\
\text { andalus. }\end{array}$ & $\begin{array}{l}\text { 䤵 } \\
\text { corund. }\end{array}$ & $\begin{array}{l}\text { 尖晶 } \\
\text { spinel }\end{array}$ & 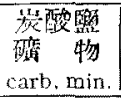 & $\begin{array}{l}\text { ダラス } \\
\text { glass }\end{array}$ \\
\hline \multicolumn{9}{|c|}{ 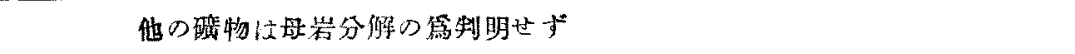 } \\
\hline- & + & + & - & + & - & - & + & + \\
\hline+ & - & - & - & - & + & + & - & + \\
\hline- & + & - & - & - & - & - & + & + \\
\hline- & + & - & - & - & - & - & - & + \\
\hline- & - & - & - & - & - & - & - & + \\
\hline- & - & - & - & - & - & - & - & + \\
\hline
\end{tabular}

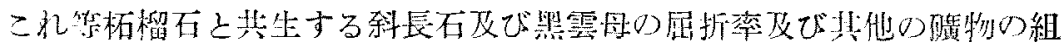

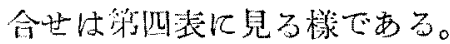

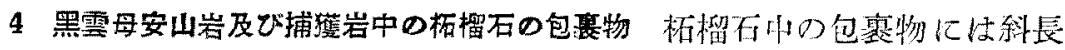

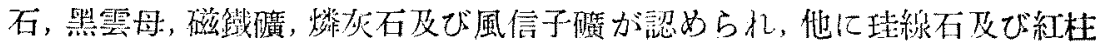

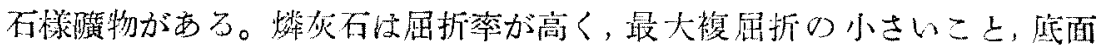

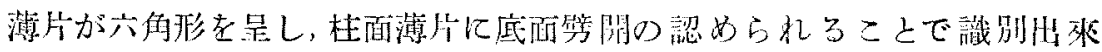

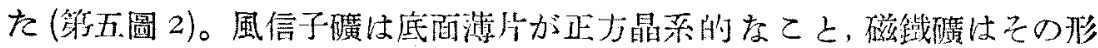

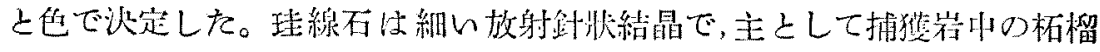
石に認められた（第四圖 3)。

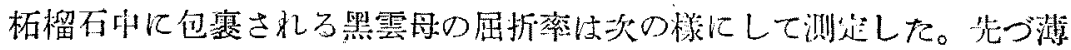

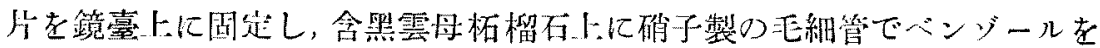
數回裙下する。柘榴石のカナダバルサムが床くなつてから，ての上に属折

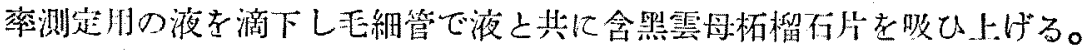

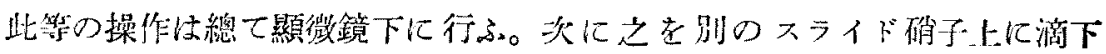
し，液を變化して照雲丹の屈折率と一致世しめる。かくして得た屈折率は

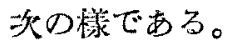




$$
\text { 柘留石中の一黑墨舟 } \quad \gamma=1.673 \text { on }(001)
$$

この伯は孯雲母安山岩中の夫と全く一致する。之は更に後述する柘榴石 の成因上興味ある關係を示寸的思ふ。

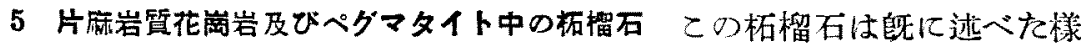
几王子南方約一籸の大鉒で探集したものである。この片麻岩質花崗岩を大

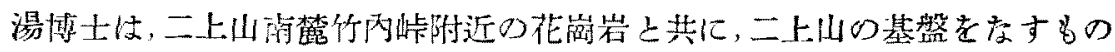
と考へら礼な。この柘榴石は雲母片岩中に进入した花厥岩中に見られる1)。 前述上同樣にして得られて屈折率 ${ }^{2}$ 之格子恒數は次の㥞である。

\begin{aligned} & 柏榴百 (Rock No. G-1) カ×ラ No. $1 \quad a_{0}=11.544 \mathrm{~A} \\ & n=1.808$ No. $4 a_{0}=11.544 \mathrm{~A} \\ &$ No. $5 \mathrm{a}_{0}=11544 \mathrm{~A} \\ &$\hline 平 均 $\mathrm{a}_{0}=11.544 \mathrm{~A}\end{aligned}$

又森本泉平學士から寄贈されたぺダマタイト中の柘榴石り屈折率子格子 恒數は次》棪である。

$$
\begin{aligned}
& \text { 柘榴百 (RM-63) カメラ No. } 1 \quad \mathrm{a}_{0}=11.589 \mathrm{~A} \\
& \mathrm{n}=1.8219(\mathrm{p}) \quad \text { No. } 5 \quad \mathrm{a}_{0}=11.587 \mathrm{~A} \\
& \text { 平均 } \mathrm{a}_{0}=11.588 \mathrm{~A}
\end{aligned}
$$

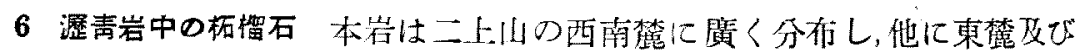

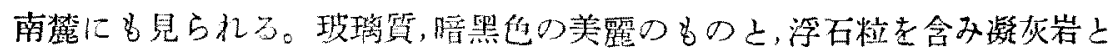
互層をなすものとがある。共に少量の柘榴石圭含有する。

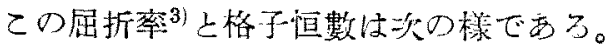

$$
\begin{aligned}
& \text { 柘榴石 (RockNo. H2) カ×ラ No. } 1 \mathrm{a}_{0}=11.547 \mathrm{~A} \\
& \mathrm{n}=1.808 \\
& \text { No. } 4 a_{0}=11.548 \mathrm{~A} \\
& \text { 平均 } a_{0}=11.548 \text { A }
\end{aligned}
$$

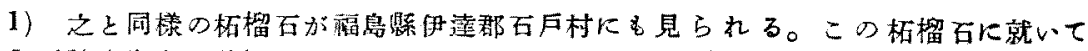

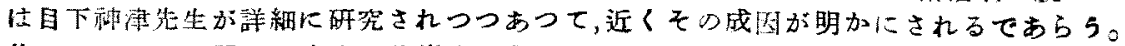

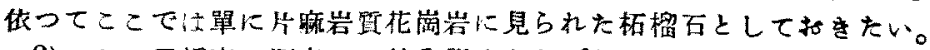

2) こり屈折率の测定には竹丙學士をわづらわした。

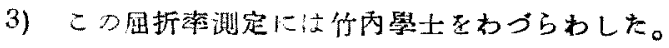




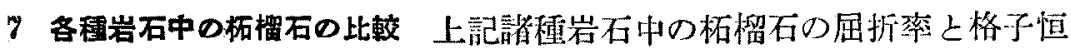
數を,比較の雹第五表に揭げる。

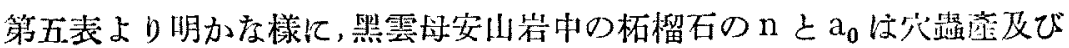
溇青岩中の夫に近似するが，捕獲岩片中の夫とは $\mathrm{a}_{0} に$ 於て明かに哄る。

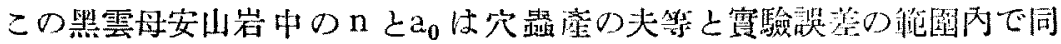
值であるから，化學成分も穴显裳の $\mathrm{A} \operatorname{lm}=67.66 \%, \mathrm{Py}=\mathrm{r} 3.20 \%, \mathrm{Sp}=4 . \mathrm{I} 3 \%, \mathrm{Gr}=8.58 \%$ 及びAnd $=6.43 \%$ と近似であるとして差支へない。

柘榴石の化學成分之座出状態との關係を述へたものに Heritsch ${ }^{1)}$ 及び Wright ${ }^{2)}$ の研究がある。この熙雲母片岩中の柘榴石及び花胕岩中の柘榴

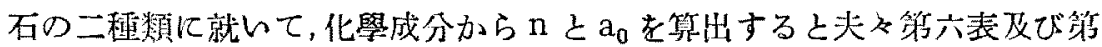
七表の様になる。ここに注意を要することはこの网者其その覓出狀態の調 查に嚴選を缺いてるる㥞に思はれることである。例へば花胕岩產柘榴石に

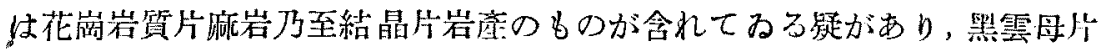
岩の場合にも同樣である。これ等に關する問題は目下神津先生の下で研究 中である。

黑雲母安山岩中の捕獲岩產柘榴石の $\mathrm{n}=\mathrm{I} .807 \mathrm{I}$ 第六表の $\mathrm{n}$ と比較す ると，No.I 及びNo. 20 と一政し, No.7, No. 9, No. Io, No. 13 及びNo.

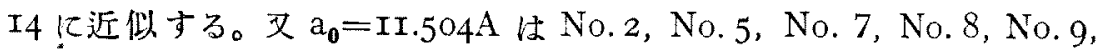
No. Io, No.II, No. I 3 及びNo.16亿近似する。從つて n 及び $\mathrm{a}_{\mathbf{0}}$ の兩者 共近似するのはNo.7,No.9, No. Io 及びNo.13である。この化學成分の 平均值は炊め樣である。

$$
\mathrm{Alm}=76.6 \%, \mathrm{Py}=15.3 \%, \mathrm{Sp}=3.4 \%, \mathrm{Gr}=4.5 \% \text { 及び And }=0.2 \%
$$

1) Heritsch, F.; Studien über den Chemismus der Granaten. N. J. M. B-B. 55, $60 \sim 91,1927$.

2) Wright, W. I.; The composition and occurrence of garnets. Am. Min. 23, $436 \sim 449,1938$. 
菊五表

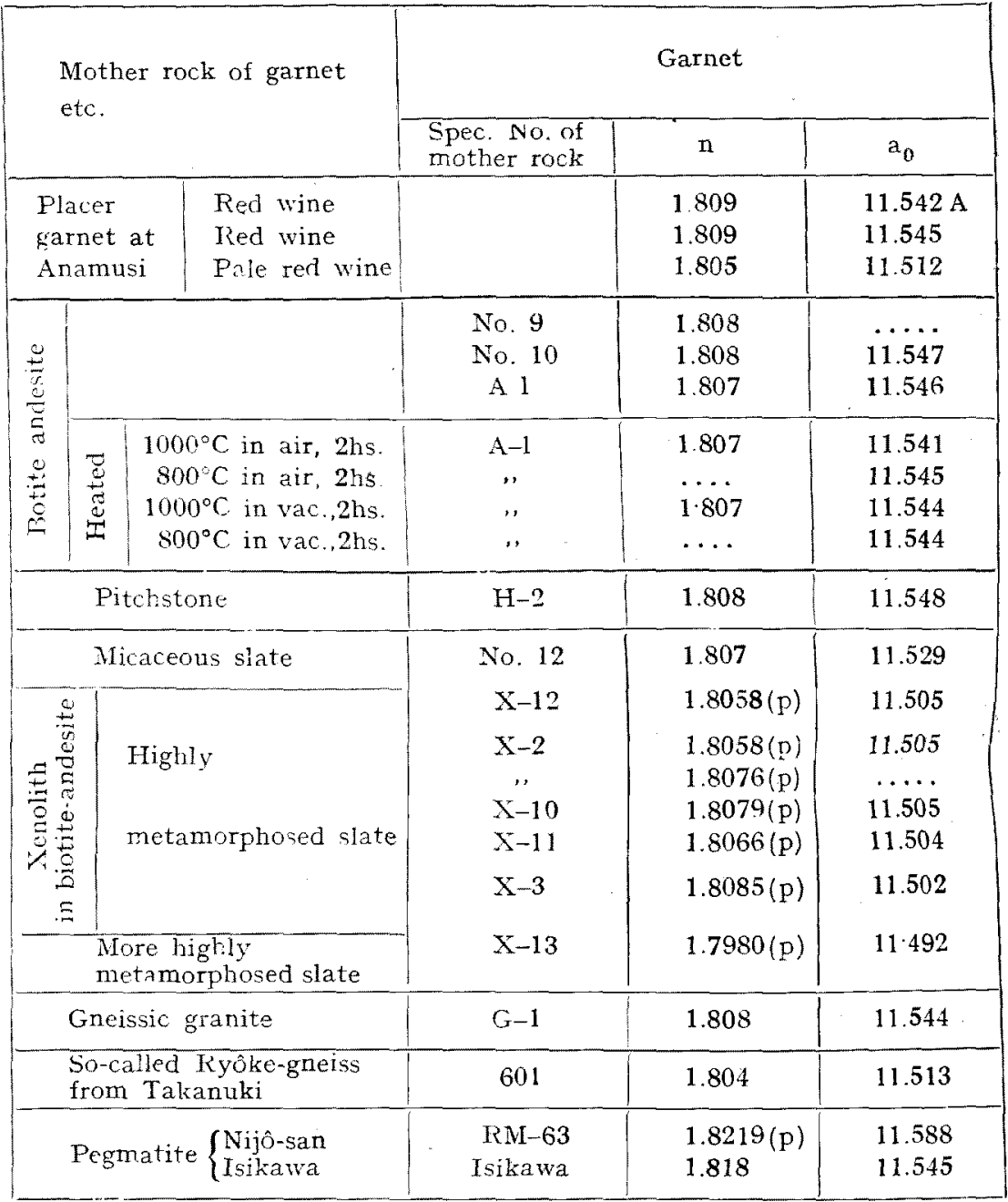

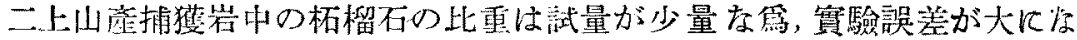
ることを慮つて測定しなかつた。從つて聯立方程式で化學成分を求めるこ

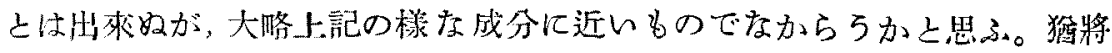
來の研究老侯つことうする。 
(Tab. 5)

\begin{tabular}{|c|c|c|c|c|c|}
\hline \multicolumn{3}{|c|}{ Associated } & \multicolumn{2}{|c|}{ Minerals } & \\
\hline \multicolumn{3}{|c|}{ Plagioclase } & \multicolumn{3}{|c|}{ Biotite } \\
\hline$a^{\prime}$ on (001) & $\gamma^{\prime}$ on $(001)$ & $\% \mathrm{An}$ & $\gamma$ on $(001)$ & $\%\left(\mathrm{Fe}_{2} \mathrm{O}_{3}+\mathrm{FeO}\right)$ & $\% \mathrm{MgO}$ \\
\hline$\cdots \cdots$ & $\therefore \ldots$ & $\ldots \ldots$ & $\ldots$ & $\cdots \cdots$ & \\
\hline$\cdots \cdots$ & $\cdots \cdots$ & $\cdots \cdots$ & $\cdots \cdots$ & $\cdots \cdots$ & $\cdots \cdots$ \\
\hline$\cdots \cdots$ & $\cdots \cdots$ & $\cdots$ & $\cdots \cdots$ & $\cdots \cdots$ & $\cdots$ \\
\hline$\ldots$ & $\ldots \ldots$ & . & $\cdots \cdots$ & $\ldots \ldots$ & $\ldots \cdots$ \\
\hline $1.550-1.544$ & $1.556-1.550$ & $43-31 \%$ & $\ddot{1} 673$ & $33 \%$ & $3 \%$ \\
\hline$\ldots \ldots$ & $\cdots \cdots$ & $\cdots \cdots$ & $\cdots \cdots$ & $\cdots \cdots$ & \\
\hline$\cdots \cdots$ & $\cdots \cdots$ & $\cdots \cdots$ & $\cdots \cdots$ & $\cdots \cdots$ & * \\
\hline$\cdots \cdots$ & $\cdots \cdots$ & $\cdots \cdots$ & $\cdots \cdots$ & $\cdots \cdots$ & $\cdots \cdots$ \\
\hline$\cdots \cdots$ & $\cdots \cdots$ & $\cdots \cdots$ & $\cdots \cdots$ & $\cdots \cdots$ & $\cdots$ \\
\hline$\cdots \cdots$ & $\cdots$ & $\ldots \ldots$ & $\ldots \ldots$ & $\ldots \ldots$ & $\cdots \cdots$ \\
\hline$\ldots \ldots$ & $\ldots \ldots$ & $\cdots$ & $\cdots$ & $\cdots \cdots$ & $\cdots \cdots$ \\
\hline$\left\{\begin{array}{l}1.566 \\
1.552\end{array}\right.$ & $\left\{\begin{array}{l}1.570 \\
1.557\end{array}\right.$ & $\left\{\begin{array}{l}70 \\
46\end{array}\right.$ & 1.643 & 18 & 12 \\
\hline$\{1.567$ & 1.571 & 72 & $\ldots \ldots$ & $\ldots \ldots$ & . \\
\hline 1.557 & 1.561 & 53 & 1.648 & 21 & 10 \\
\hline 1.566 & 1.570 & 70 & 1.643 & 18 & 12 \\
\hline$\left\{\begin{array}{l}1.568 \\
1.552\end{array}\right.$ & $\left\{\begin{array}{l}1.571 \\
1.557\end{array}\right.$ & $\left\{\begin{array}{l}73 \\
46\end{array}\right.$ & 1.643 & 18 & 12 \\
\hline f 1.565 & $\int 1.569$ & 68 & 1648 & 21 & 10 \\
\hline$\{1.553$ & $\{1.559$ & $\{4$ & & & 10 \\
\hline$\cdots \cdots$ & $\cdots \cdots$ & . & . & $\ldots \ldots$ & . \\
\hline$\cdots \cdots$ & $\cdots \cdots$ & $\cdots \cdots$ & $\cdots$ & $\cdots$ & $\cdots \cdots$ \\
\hline$\cdots \cdots$ & $\cdots \cdots$ & $\ldots$ & $\cdots \cdots$ & $\cdots \ldots$ & $\cdots \cdots$ \\
\hline$\ldots \ldots$ & $\cdots \cdots$ & $\cdots \cdots$ & $\cdots \cdots$ & $\cdots \cdots$ & \\
\hline
\end{tabular}

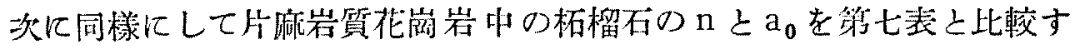
ると, $\mathrm{n}=1.808$ はo. 7 と饪く一致し, No. 2, No. 5, No.6, No.8, No. 9, No.Io,No.II 及びNo. I6 亿近似する。叉 $a_{0}=I x .544$ A No. 5 , No. I4 に近似する。從つてnと $\mathrm{a}_{0}$ の网者共近似するのはNo.5である。この化 


\begin{tabular}{|l|r|r|r|r|r|r|r|r|r|r|}
\hline \multicolumn{1}{|c|}{ No. } & 1 & 2 & 3 & 4 & 5 & 6 & 7 & 8 & 9 & 10 \\
\hline $\mathrm{n}$ & 1.807 & 1.796 & 1800 & 1.814 & 1.816 & 1.815 & 1.810 & 1.813 & 1.803 & 1.808 \\
$\mathrm{a}_{0}$ & 11.550 & 11.501 & 11.523 & 11.578 & 11.507 & 11.513 & 11.505 & 11.513 & 11.509 & 11.508 \\
\hline $\mathrm{Alm}$ & 65.0 & 67.0 & 71.0 & 67.1 & 87.4 & 86.7 & 80.8 & 82.4 & 74.0 & 78.3 \\
$\mathrm{Py}$ & 16.9 & 29.1 & 16.2 & 6.7 & 7.8 & 7.0 & 12.4 & 8.6 & 16.8 & 14.7 \\
$\mathrm{Sp}$ & 5.0 & - & 3.0 & 7.8 & - & - & 2.7 & 3.2 & 3.6 & 2.2 \\
$\mathrm{Gr}$ & 5.9 & - & 9.8 & 10.9 & 4.8 & 6.3 & 4.1 & 5.8 & 5.6 & 3.8 \\
$\mathrm{And}$ & 7.2 & 3.9 & - & 7.5 & - & - & - & - & - & 1.0 \\
\hline
\end{tabular}

\begin{tabular}{|l|r|r|r|r|r|r|r|r|}
\hline No. & 1 & 2 & 3 & 4 & 5 & 6 & 7 & 8 \\
\hline $\mathrm{n}$ & 1.821 & 1.810 & 1.796 & 1.820 & 1.812 & 1.810 & 1.808 & 1.804 \\
$\mathrm{a}_{0}$ & 11.525 & 11.560 & 11.417 & 11.528 & 11.538 & 11.559 & 11.567 & 11.573 \\
\hline $\mathrm{Alm}$ & 75.7 & 32.6 & 60.5 & 65.2 & 57.0 & 32.5 & 41.6 & 19.1 \\
$\mathrm{Py}$ & -- & - & 2.9 & - & 3.3 & - & - & 1.0 \\
$\mathrm{Sp}$ & 21.7 & 66.9 & 33.7 & 34.8 & 36.8 & 67.5 & 52.0 & 78.4 \\
$\mathrm{Gr}$ & 2.6 & 0.5 & 1.9 & - & 2.9 & - & 6.4 & 1.5 \\
And & - & - & - & - & - & - & - & - \\
\hline
\end{tabular}

學成分は

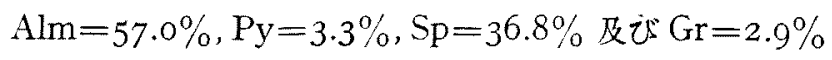

である。

この比重も前述と同樣に測定し得なかつたが化學成分は上記成分に近似 のものであら5と今は想像して置く。

8 柘㨨石の $\mathrm{a}_{0}$ 及び $\mathrm{n}$ に對する溫度の影響 二ト山柘榴石の成因を考察す る上に，若し同火山岩嶈の活動罍時に於ける物理的及び化學的條件に近い 狀態で本柘榴石に龂する熱的影響兾驗的に知ることが出本るならば，余 等は焰一層進んだ成因を教笲するととが出來るのであるが，現在ではこの

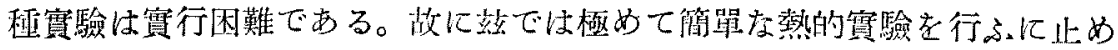
た。即ち二上山座柘榴石を, $800^{\circ} \mathrm{C}$ 或は $1000^{\circ} \mathrm{C}$ に空氣中或は真空中で 2 時間加熱した時に， $\mathrm{a}_{\mathbf{0}} に$ にん影響を與へるかを檢したのである。この場 
(Tab. 6)

\begin{tabular}{|r|r|r|r|r|r|r|r|r|r|r|r|}
\hline 11 & 12 & 13 & 14 & 15 & 16 & 17 & 18 & 19 & 20 & 21 & 22 \\
\hline 1.801 & 1.796 & 1.803 & 1.812 & 1.826 & 1.814 & 1.796 & 1.831 & 1.799 & 1.807 & 1.782 & 1.825 \\
11.496 & 11.489 & 11.506 & 11.532 & 11.564 & 11.508 & 11.531 & 11.549 & 11.514 & 11.525 & 11.551 & 11.553 \\
\hline 74.6 & 71.4 & 73.4 & 80.9 & 76.3 & 86.5 & 58.0 & 72.2 & 65.5 & 78.0 & 57.2 & 71.8 \\
20.3 & 25.2 & 17.1 & 5.8 & 10.2 & 10.9 & 16.0 & 0.6 & 27.5 & 8.5 & 23.0 & 4.0 \\
2.3 & 1.6 & 4.9 & 2.2 & - & - & 18.0 & 1.8 & 0.9 & 4.9 & - & 16.1 \\
2.8 & 1.8 & 4.6 & 11.1 & - & 26 & 8.0 & 8.8 & - & 8.6 & 19.8 & - \\
- & - & - & - & 13.5 & - & - & 16.6 & 6.1 & - & - & 8.1 \\
\hline
\end{tabular}

('Tab, 7)

\begin{tabular}{|c|c|c|c|r|r|r|r|}
\hline 9 & \multicolumn{1}{|c|}{10} & 11 & 12 & 13 & 14 & 15 & 16 \\
\hline 1.813 & 1.811 & 1.811 & 1.829 & 1.819 & 1.819 & 1.816 & 1.812 \\
11.581 & 11.507 & 11.499 & 11.513 & 11.531 & 11.533 & 11.567 & 11.516 \\
\hline 31.0 & 79.9 & 79.8 & 91.4 & 71.4 & 68.5 & 40.9 & 73.0 \\
- & 11.3 & 17.2 & 0.9 & 7.0 & 6.8 & - & 13.0 \\
64.0 & 4.8 & - & 5.3 & 17.3 & 20.7 & 55.7 & 10.8 \\
1.0 & 4.0 & - & - & - & - & - & - \\
4.0 & - & 3.0 & 2.4 & 4.3 & 4.0 & 3.4 & 3.2 \\
\hline
\end{tabular}

合柘榴石の泠却は電粷垭の白然冷却に委した。

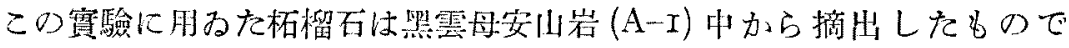
あるから，其性㯺は第五裁に見るものである。

加熱したるのを見ると，結晶に破壤されて小粒となつてるるものがある

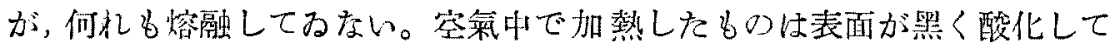

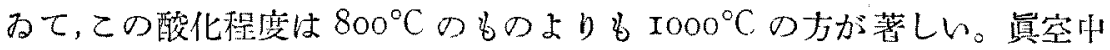

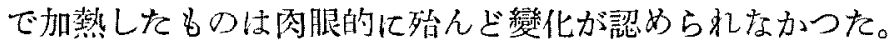

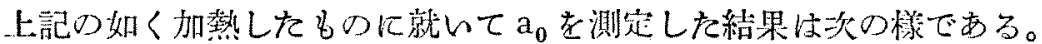
空氣中加熱

$800^{\circ} \mathrm{C} \ldots \mathrm{a}_{0}=11.545 \mathrm{~A}$ (カメラNo.1 11.537A, No.411.542A 及びNo.5 11.543A) $1000^{\circ} \mathrm{C} \ldots \mathrm{a}_{0}=11.541 \mathrm{~A}$ (が 7 No.2 11.543A, No.6 11.547A 及び No.8 11.544A)

瀑案中加熱

$800^{\circ} \mathrm{C} \ldots \mathrm{a}_{0}=11.544 \mathrm{~A}$ (カメラ No. 111.541A, No.611.547A 及びNo.811.544A) $1000^{\circ} \mathrm{C} \ldots \mathrm{a}_{0}=11.544 \mathrm{~A}$ (カメタNo.1 11.546A, No.411.542A 及びNo.5 11.545A) 


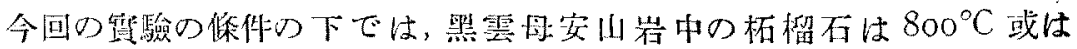

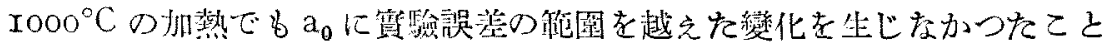
が知られた。

要するに，この杽柘榴石は $1000^{\circ} \mathrm{C}$ 迄の乾燥加熱では，其成分に變化责柬 さないよ言ひ得る。

空武中及び傎空中に $1000^{\circ} \mathrm{C} て ゙ 2$ 時間加熱した上記のものを加熱せざる 必の上其に同一薄斻中に於て分散浸液法で屈折率を测定した所皆 $\mathrm{n}=1.807$

で闹做を示した。

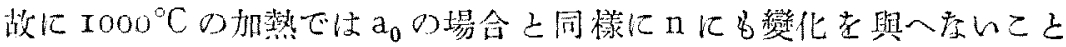
が知られた。

\section{VII 柘㨨石の成因に關する考察}

火成岩中の柘㨨石の成因に就いて若へて見ると

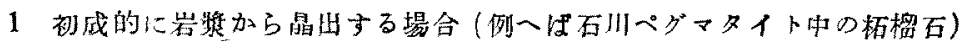

2 火山岩獎に原因するこニーマトリテック作用で晶时する場合（例一代和田忬流 紋岩中心柘榴石)

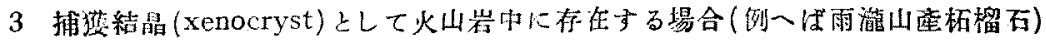

4 捕獲岩を熔鳋同化した絬果岩繁中下晶出する場合 等が舉げられる，澄其他の成因乎豫想される之思る。

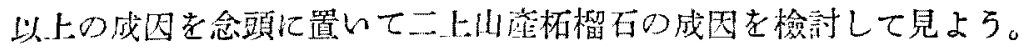

二上山安山岩中の柘榴石が其捕獲岩已成因上密接の關係を有するならん とは一般に考察さるっ所である。然し捕獲岩山心既成柘榴石が安山岩中に 捕獲結晶(xenocryst)として包藏されたるものか，或は捕獲岩物質が安山岩

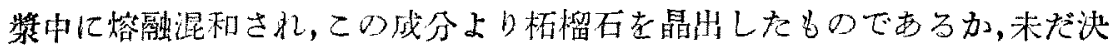
する所がなかつた。

この問題を檢討する嘕に先づ安山岩中の柘榴在之捕獲岩中の柘榴石との

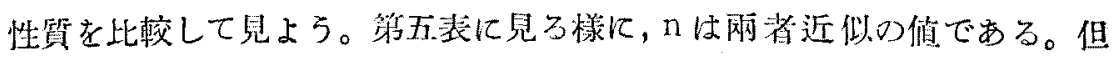
し测定方法を全部プリズム法に一定することが出來をかつたので, 浸液分 
散㳂の結果は小数點以下三位の細論に入ることは出來ない。これに反し て $\mathrm{a}_{0}$ は兩者明かに區别することが出來る。郎ち安汕岩中の柘榴石は約 II.546 $\mathrm{A}^{1)}$ であるに對し，捕獲岩中の柘榴石は一般に約 II.504 $\mathrm{A}^{2)}$ であ. る。要するに安山岩中の柘榴石は捕獲岩中の柘榴石之其物狸性從つて化學 成分に於て異る所があると言ふてとが出來る。故に安山岩中の柘榴石と 捕獾岩中の柘榴石とは簧る成因のbのではないかと先づ念頭に浮ぶので ある。

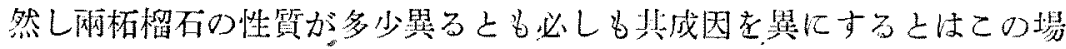
合值ちに斷じ得なんとの論者もあると思はれる。其理由の一つとして，捕

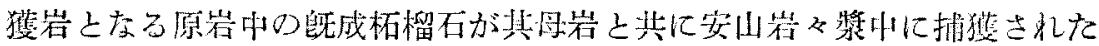

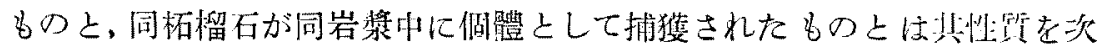
の如き作用で或程度變化し得ろと考へられるからである。即ち後者は岩漿 に直接接して岩槳の約 $800^{\circ} \mathrm{C} \sim 1000^{\circ} \mathrm{C}$ 或は上り高き溫度の影響を受け，前 者は捕獲岩中に包圍されて同じ岩奬の溫度を受けたのである。この䋹果之 して网者の柘榴石の性質に多少の黄異在生ぜしむることあり得るは，柘榴 石が固溶體者形成することから容易に推考される所である。但し $800^{\circ} \mathrm{C}$

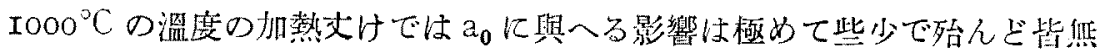
であることは今回の實驗の結果で朋かである。

故に柘榴石が揢融しない限りは兩柘榴石間に尘ずろ變化は極めて少い上 推される，換言すれば、記 $\mathrm{a}_{0}$ の上に $0.042 \mathrm{~A}$ の俈異あるは雨結晶の形成さ る」場合に單に溫度の影響のみならず僅かではあるが他の成因上に差異が

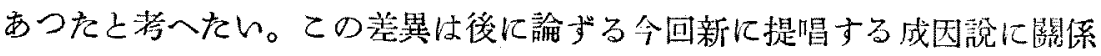
する結晶母液の化學成分の差異に踏することが合理的であると思はれる。

1) 例外として淡紅色のものは $\mathrm{a}_{0}=11.512 \mathrm{~A}$ である。

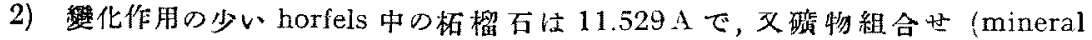

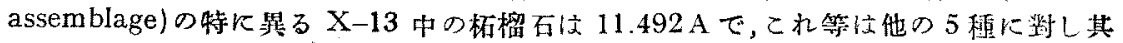

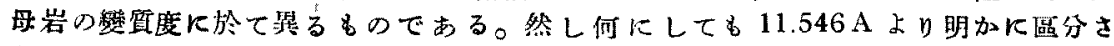
机了。 
ト記に於ては柘㨨石は岩槳小に捕獲さる」前に既に結晶として存在せる こと者前提としての考察である。ての前提が果して現在二上山に於て觀 察し得らる」謢現象と對比して直ちに說明され得るや否やを檢討して見 よう。

今回抔集した数多き捕獲岩中に分们する柘榴石を觀るに其數は沃して多

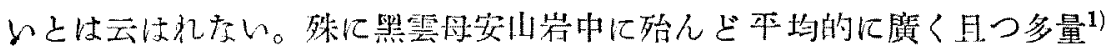
几分布するもの上比較すると安山岩中の柘榴石を捕獲岩中のもの上り供給 されたと考ふることは困難である。この事は毁に諸氏が墖ぜられて所で余 等も亦同感である。故に現在思万捕獾岩中の柘榴石以上の大量の同礦物が

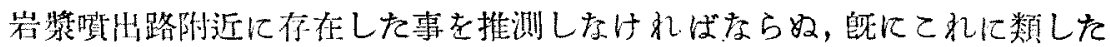
洘へJ先した名ないではない。

然しかくの如き礦物層が二上山基盤に黄く存在するもの上すれば，同火 山を䨀成する螾岩中獨り熙雲母安川岩流のみに多量の柘榴石を含み，他の 三種り熔岩流中に恛極めて少量のみを含さことの事實在說明するに困難

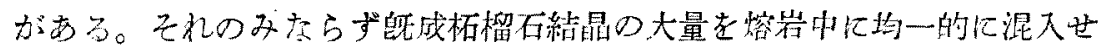
しむるには熔岩の粘度が相虽小で且つ攬排作朋を認めなけ礼ばなら收。其

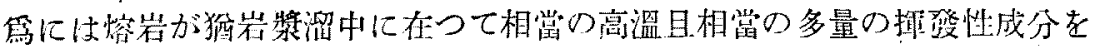
持つ場合考考ふることが必要である。か」る狀態にある熔岩中に外來柘榴 石結晶を混入世しむれば，直ち滛触を生ずるは阴かである。然るに安山 岩中の柘榴石至檢するに斑晶㪴長石の晶出時代に晶出した柘榴石は歷然た る自形老呈して科長石中に見られる。

若し柘榴石の睡成結晶の存在老假定せずして，その代りに高溫之高厴に

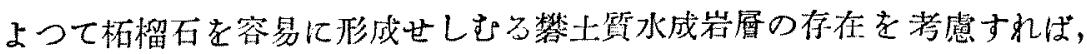
說明はより容易となると思はれる。然し何れにしてる黑雲母安山岩が他の 聺岩に比し特に多量の捕獾岩を包含することに就いては特别の說明を要す

1) $1 \mathrm{~cm}$ 立方中に約五個の标榴石を含む。 


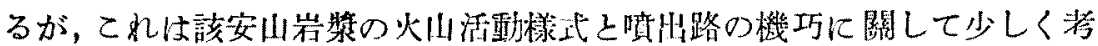
虑をめぐらせ代其䛦明は必しも困難ではなんと思ふ。

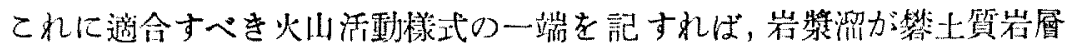

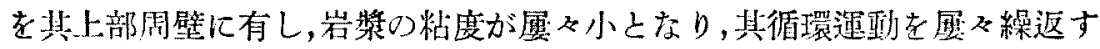

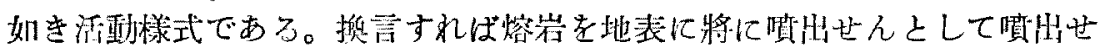

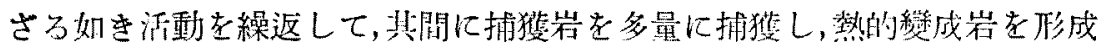

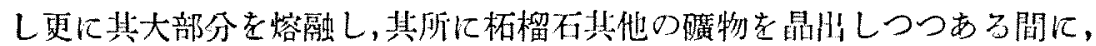
逐に听火の大活動を演じたる如きものである。

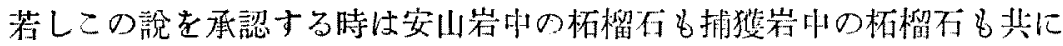

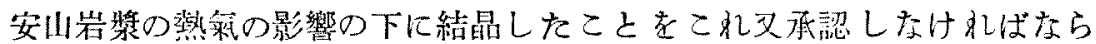

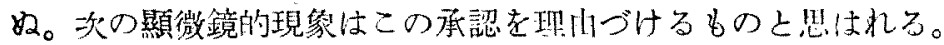

1 宛山岩中心柘榴石は一方では自形の斜長石を包裹するが，他方では科長石に包

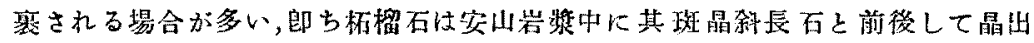
したのである。

2 安山岩中に於て柘榴石が科長石中に包変される場合には其外形は必ず自形であ る。これに反し石基に㨁接取り圆むれて居る部分は著しく融触されて居るすの

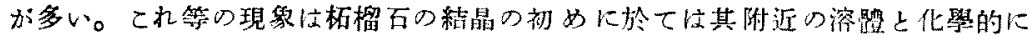

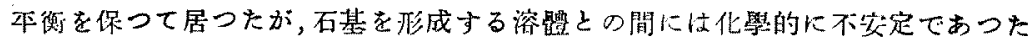

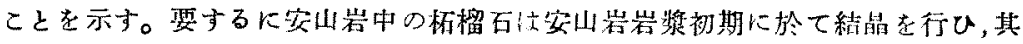

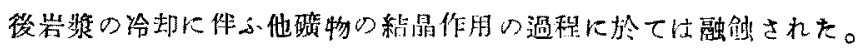

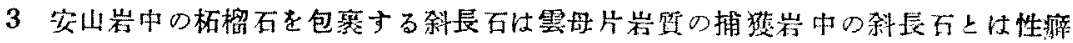
を装にする。前者には累帶構造を旺する場合あるも，後者にはこれなるが如きで ある。

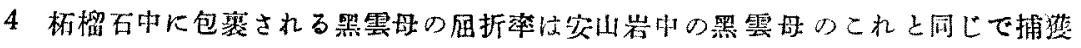
岩屾のものとは大に䈍なる。

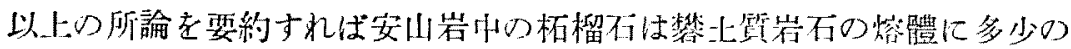

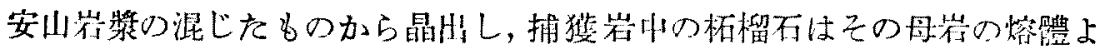

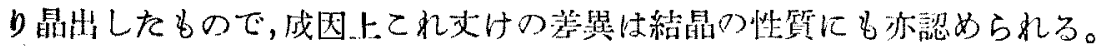

但し安山岩中の柘榴石は, 全部始めから安川岩獎中で晶山したもののみ ではない，始め山岩漿中に捕獲された㞸石中で絬晶し，安川岩の石基がまだ 


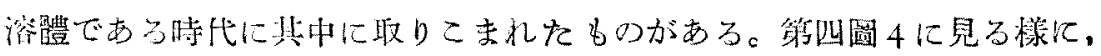

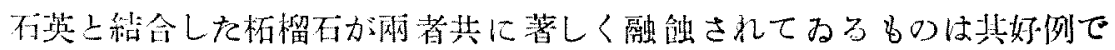
ある。

捕䇚岩中の柘榴石で特に吾人の注意を惹くことは絬晶が判然たる自形を 呈するもの或にこ机に近いものが多いことである。捕獲岩中には結晶問陸 にグラスを存し，唀明新鮮なる再結晶の斜長石が良く櫒達するから明かに

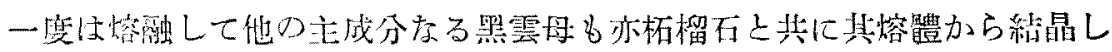

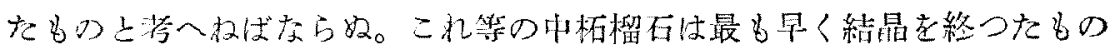

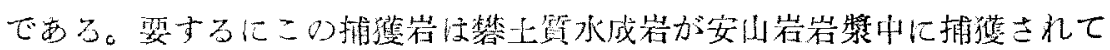

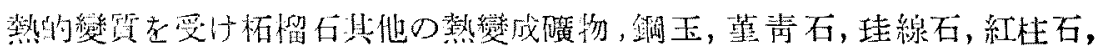

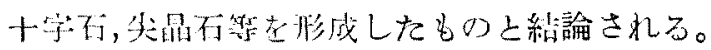

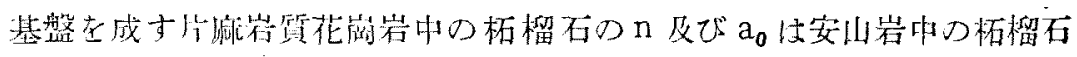

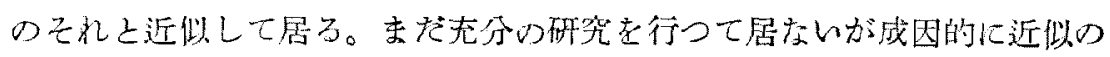
跕があると照は㣗る，郎ち攀土筫岩石の混在の如きであらう。

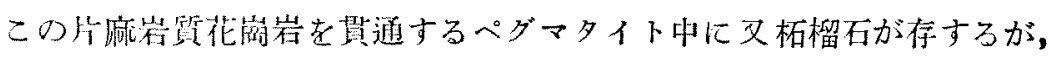

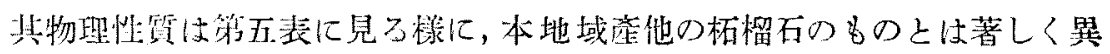

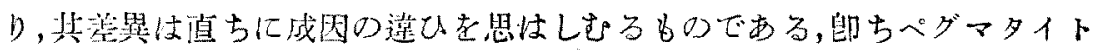

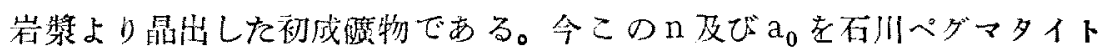
中の柘榴石のそれ等と比较しても雨等共に前者の方が猴著しく高い。

\section{VIII 總括}

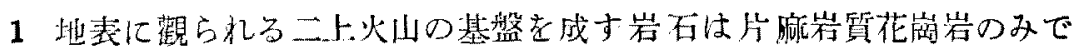

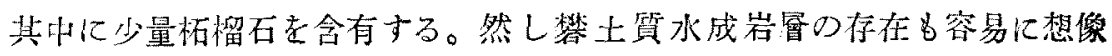
される。

2 吉澤學士に從一ば二上火山の本體を構成する熔岩は下部上り䇥青岩，

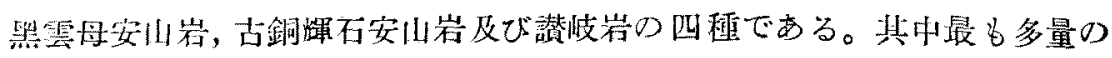
柘榴石を含有するものは熙雲母安山岩で均一的に分布し，概测によれば I Cc 中に䄪五㑬の割合で存在し，その大さは一般に淔徑 $2 \mathrm{~mm}$ 以下であ 


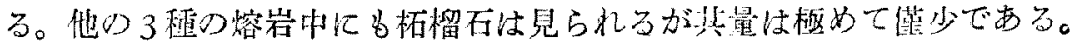

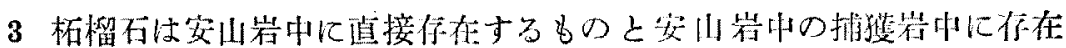
するもの上ある。前者のnはI.807〜I.809で, 後者のn 特别の場合を 除きI.806〜r.809であるから，ての性質では雨篔を區别するここが出來な

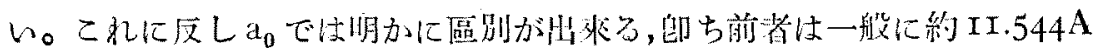
であるが後省の多くはII.505A である。

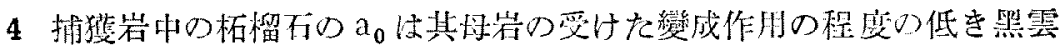

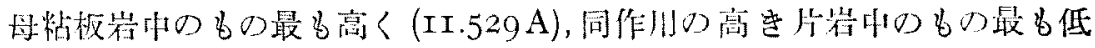

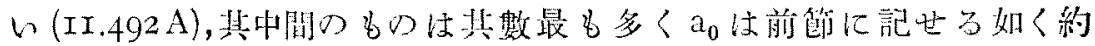

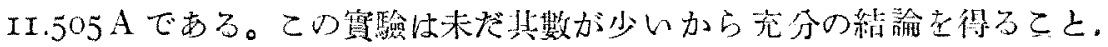
が出來ないが，今回の結果では上記の如き關係が言はれる。

5 安山牢中の柘榴石で石基に直接包まれるものは著しい融触を受けた ものが多い，然るに玟晶科長石中のものは自形索是する。又柘榴石中の斜

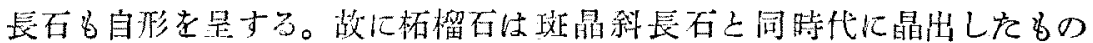
で,勿論母液之化學平衡を保つたが，洪媵石基を成寸溶體とは化學的に不安

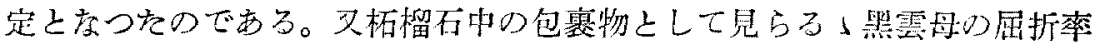
は安山岩の品雲母のそれと同じであつて捕獲岩州の黑雲母の屈折率と著し

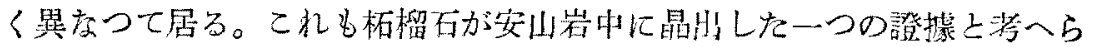
れる。

6 今回研笁した捕獲岩は礐土質水成岩から變留したものが大部分であ る。この變成岩は變質の程度で外觀老異にし, 變筫度の尠きものは殆んと

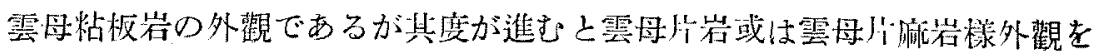

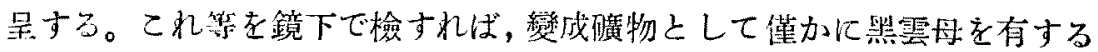

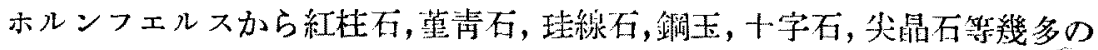

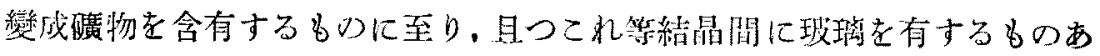

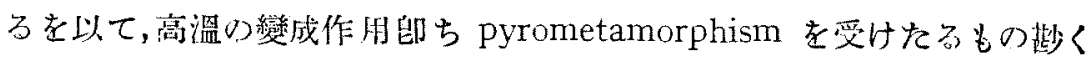
ないてとは朋である。これ以上の揮淡成分と高溫の影響を受けたるのは 


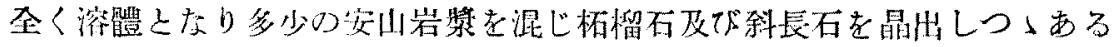

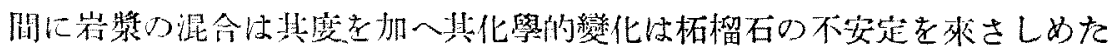
のであらら。

装するに，安山岩中に品出した柘榴石の母液上捕獲岩中に晶出した柘榴

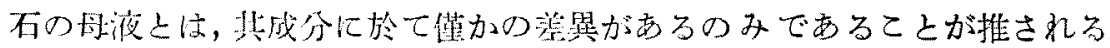

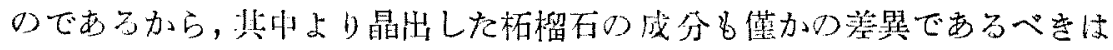
虽然である。

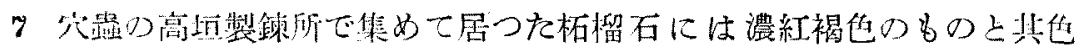
の源い紅䙓色のものとが區别される。前者は $\mathrm{n}=\mathrm{I} .809$ 及び $\mathrm{a}_{0}=\mathrm{II} .545 \mathrm{~A}$

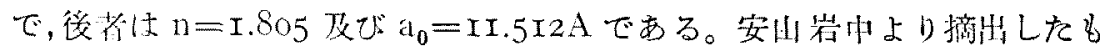

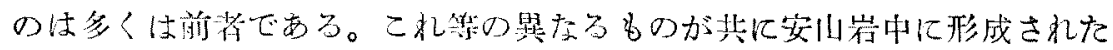

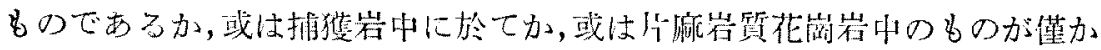
ではあつても泥大したものか不焩である。

8 安山岩 $(\mathrm{A}-\mathrm{I})$ 中の柘榴石を摘出し空莱中及び県空中で $800^{\circ} \mathrm{C}$ 及び $1000^{\circ} \mathrm{C}$ に备々 2 時閒加熱したが $\mathrm{n}$ 及び $\mathrm{a}_{\mathbf{0}}$ には殆んど變化がなかつた。

9 濃紅裩色の柘榴石の化學成分は河野博士の分析で明かであるが，其端 成分は $\mathrm{Alm}=67.66 \%, \mathrm{Py}=\mathrm{r} 3.20 \%, \mathrm{Sp}=4.13 \%, \mathrm{Gr}=8.58 \%$ 及び And $=6.43 \%$ である。

本柘榴石の物理恒數は $\mathrm{n}=\mathrm{I} .809, \mathrm{a}_{0}=\mathrm{II} .542 \mathrm{~A}$ 及び $\mathrm{G}_{4}=4 . \mathrm{IO} 4$ である から、これ等より篎出しを端成分は $\mathrm{Alm}=67.34 \%, \mathrm{Py}=\mathrm{I} 3.07 \%, \mathrm{Sp}=$ $4.5 \mathrm{I} \%, \mathrm{Gr}=8.64 \%$ 及び And=6.44\%である。

安川岩中に裳寸る柘㨨石はその物理性に多少異なるものあつても上記化 學成分に近似の值のものであると信ずる。

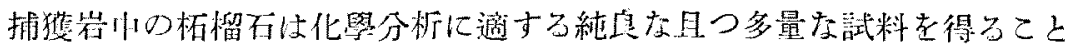

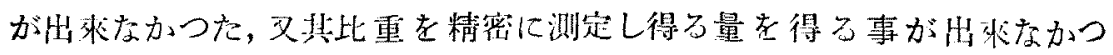
た。故に物理恒數から端成分の算出老行ふことは出來なかつた。

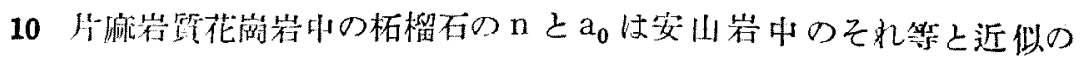


值であることは第五表に見る樣で, 若しこれ等が混交すれば區别は困難で あると思ふ。かく性質の近似するは其成因が似て居るからで, 花崩岩中に 攀土質水成岩が捕獲されて其中に柘榴石が形成されたからですらら。

11 捕獲岩中の柘榴石の $\mathrm{n}$ と $\mathrm{a}_{0}$ とに他の地域の變成岩中の柘榴石の n

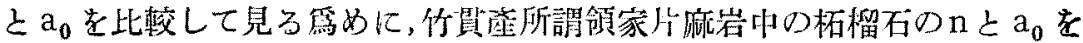
測定した。第五表に見る様に後者は捕獲岩印の熙雲母粘板岩中の柘榴石と 一啳變質作用の進んだ雲舟片岩中の柘榴石との中間性を示す。

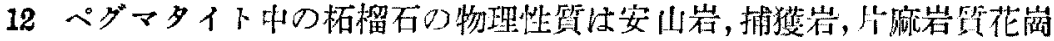
岩中の物理制質と明かに區制されるるのである。

最後に本研究儿政し終始變らざる御熱心を以て御指尊を晹へる神津先生 に再び謝意を捧げる。

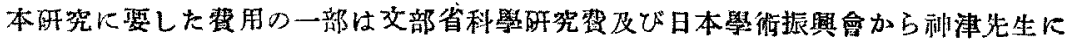

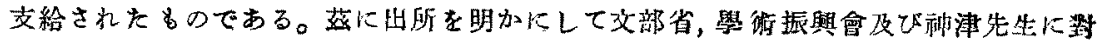
し深謝の意を表する。

\section{弓長嶺産柘榴石の研究 (III)}

産出狀態 (2)

Studies of garnet from Kyûchôrei, Manchoukuo (III)

Modes of occurrence (2)

理學士 待 場勇 (I. Matiba)

\section{B 柘㨨石カンミングトナイト岩及び柘㨨石直閃石岩}

1 産出狀態 柘榴石カンミングトナイト岩之柘榴石直閃石岩之は肉腿的 には殆んど區别出來ない程よく類似し，唯顯微鏡的にカンミンダトナイト (cummingtonite) 之直閃石 (anthophyllite) と區别し得るもので, 岩石 の產狀及び性筫は全く類似するものである。本地域に於て柘榴石かンミン グトナイト岩及び柘榴石㨁閃石岩が見られるのは次に示寸做處である。 